\title{
ANTROPONIMSKI GLIFOVI U KODEKSU XOLOTL
}

\section{Sažetak}

Kodeks Šolotl jedan je od najstarijih piktografskih akolua-teskočkih dokumenata kartografsko-istorijskog tipa koji govori o dolasku Ćićimeka u Teskoko pod vođstvom Šoltla, njihovom kontaktu sa starosedeocima, kao i o procesu akulturacije. ${ }^{1} \mathrm{U}$ ovom radu daje se lingvistička analiza antroponima prema tipu i strukturi glifa, u skladu sa Manrikeovom (1988) distinkcijom između direktnog i inidrektnog logograma, i Vitakerovom podelom na prosti, složeni i sliveni glif. Analizom su obuhvaćeni samo antroponimi sa prvog lista kodeksa.

Ključne reči: kodeks, piktografsko pismo, glif, direktni logogram, indirektni logogram, fonogram, rebus, Ćićimeci, Šolotl, antroponim

\section{Uvod}

Kodeks Šolotl sastoji se od 10 listova oslikanih na papiru amate ${ }^{2}$, koji se danas čuvaju u Nacionalnoj biblioteci u Parizu u kolekciji Aubin-Goupil, pod naslovom Histoire Chichimèque $^{3}$. Vreme njegovog nastanka nije sa sigurnošću utvrđeno. lako postkolonijalni hroničar Alva Ištlišoćitl (1985) tvrdi da je nastao u vreme vladara Nesaualkojotla (XV vek), dakle, u pretkolumbovskom Meksiku, analiza samog dokumenta ukazuje na prisustvo evropskog uticaja u načinu predstavljanja sunca, zastave, zvezda i drveća (cf.

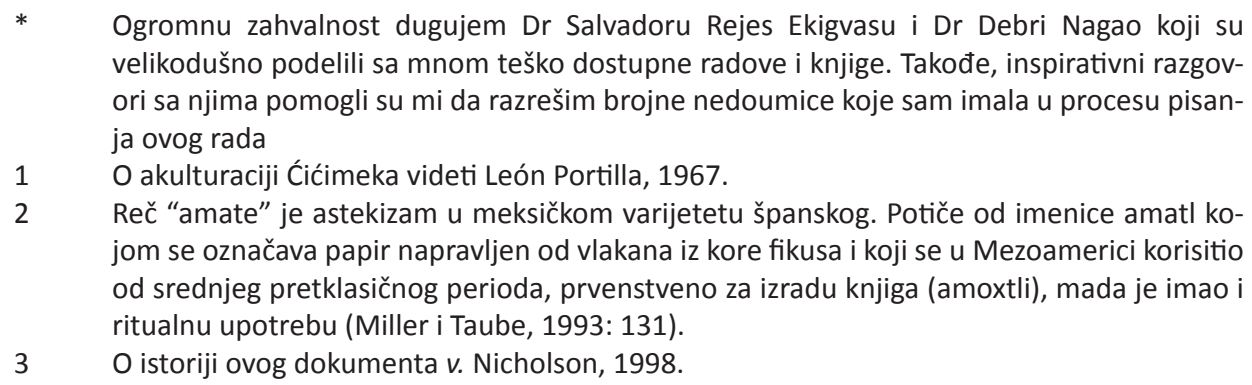
velikodušno podelili sa mnom teško dostupne radove i knjige. Takođe, inspirativni razgovori sa njima pomogli su mi da razrešim brojne nedoumice koje sam imala u procesu pisanja ovog rada

$1 \quad$ O akulturaciji Ćićimeka videti León Portilla, 1967.

2 Reč "amate" je astekizam u meksičkom varijetetu španskog. Potiče od imenice amatl kojom se označava papir napravljen od vlakana iz kore fikusa i koji se u Mezoamerici korisitio od srednjeg pretklasičnog perioda, prvenstveno za izradu knjiga (amoxtli), mada je imao i ritualnu upotrebu (Miller i Taube, 1993: 131). O istoriji ovog dokumenta $v$. Nicholson, 1998. 


\section{Philology of Culture}

Dibble, 1980). Stoga je uglavnom prihvaćeno mišljenje da je nastao nakon španskog osvajanja, između 1542. i 1546. godine, mada Marc Thouvenot (2012) i njegovi saradnici kategorički odbacuju ovakav zaključak, smatrajući da je dokument, ipak, starijeg datuma.

Prvi list kodeksa obuhvata vremenski period od 25 godina i govori o prvom susretu nomadskih plemena sa tekovinama toltečke civilizacije centralnog Meksika. Odatle saznajemo da nakon Šolotla dolazi šest ćićimečkih vođa koji predvode manje grupe ljudi i da oni stižu sukcesivno godinu za godinom. Poput ostalih teskočkih dokumenata, Mapi Tlocin i Mapi Kinacin, Ćićimeci su i u kodeksu Šolotl predstavljeni kao nomadi, sa lukom i strelom, ogrnuti kožom životinja koje su ubijali. Prema tvrdnji Leon Portilje (1967: 66), govorili su različitim jezicima (otomi, pame, masaua), zbog čega su ih nazivali popolocas, odnosno, "varvari".

Slika $1^{4}$ : Kodeks Šolotl, list 1

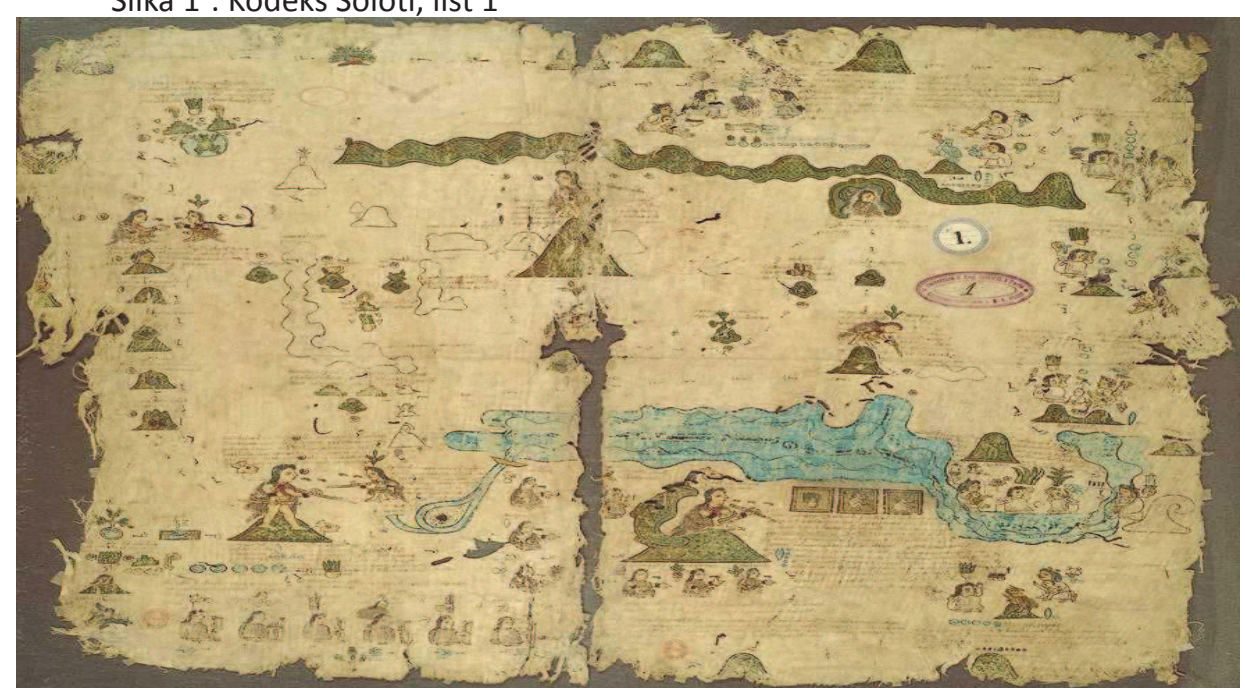

\section{2. $O$ astečkom pismu}

Drevni Asteci beležili su svoja znanja, mitove, istoriju i administrativne podatke na papiru amate, pergamentima od životinjske kože, platnima od pamuka ${ }^{5}$, ili u kamenu, poput Tisokovog ili Moktesuminog kamena. O prirodi njihovog pisma najbolje govori etimologija same reči tlacuilolli ("pismo"), koja potiče od glagola icuiloa sa značenjem "pisati", "crtati/slikati", "uklesati", "štampati" (Clavijero, 1780; Molina, 2004, Wolge-

$4 \quad$ Sve slike i ilustracije iz ovog rada preuzete iz Tlachia [online]. Universidad Nacional Autónoma de México [Ciudad Universitaria, México D.F.]: 2012 [pristupljeno 24/11/2016]. Dostupno na <http://tlachia.iib.unam.mx>

Leon Portilja ih prvenstveno povezuje sa kolonijalnim kodeksima, mada ističe da su se koristili i u prehispanskom periodu (2012:142). 
muth, 2002; Cortés y Zedeño, 1765). Kako navodi Mikulska Dąbrowska (2008: 28), razlika između "pisati" i "crtati" ne postoji ni u majanskom jeziku, u kojem ts'ib obuhvata oba pomenuta značenja.

Formalno posmatrano, astečko pismo je piktografskog tipa, ali nam to ništa ne govori o vrednostima tih slikovnih znakova. Wittaker (2010b: 137) ga opisuje kao hijeroglifsko pismo "in the sense that most signs have a pictorial, rather than abstract form, irrespective of function". Sa funkcionalnog stanovišta, piktogrami ili hijeroglifi mogu imati različite vrednosti, te se stoga razlikuju dve vrste znakova (Lacadena, 2008; Wittaker 2009, Zender, 2008)

1) Logogrami ${ }^{6}$, koji transkribuju leksičke morfeme. Manrike (1989) razlikuje direktne i indirektne logograme ${ }^{7}$ u zavisnosti od toga da li se njime transkribuje pojam koji je predstavljen, ili pak ideja koja je povezana sa tim pojmom. Tako, na primer, crtež sunca može biti i direktni logogram ("sunce"), ali i indirektni ("toplota", "dan"). Neophodno je napomenuti da su logogrami najšečće osnove reči ali, ne i isključivo. Kako ističe Wittaker (2009: 64) "the credo that the nominal stem alone is the value of a logogram is incorrect [...] we have a number of instances where it is likely that the scribe intended the nominal suffix, singular or plural, to be included in the reading", kao na primer u Mitl ili Iztaccuauhtli, gde su finalno -tl/-tli sufiksi za množinu imenica. Osim toga, oni daju informaciju o vokalskoj dužini, ili glotalnom plozivu koji su prisutnim u govoru.

2) Fonogrami -transkribuju kako pojedinačne glasove, tako i slogove. I dok Lacadena instistira na tome da tome da su slogovi isključivo otvoreni ${ }^{8}$, tj. oni sa strukturom (C)V, Wittaker (2009:62) pokazuje da takav stav nema utemeljenje, jer svi primeri fonetizma u astečkom pismu potiču od logograma primenom rebusa. Sa druge strane, navodi primere silabarija iz drugih jezika koji uključuju i zatvorene slogove.

Kombinovanjem ove dve vrste znakova primenom principa rebusa i, po potrebi, fonetske dopune, dobijaju se složeni i sliveni glifovi (mada postoje i prosti, u slučajevima kada se glif sastoji od samo jednog znaka). Razlika između složenih i slivenih glifova je u tome što je kod slivenih, jedan od elemenata inkorporiran u drugi (v. glif 18), dok je kod složenih svaki od elemenata autonoman.

Ipak, astečkom pismu se još od kolonijalnog perioda poriče status pisma9. Ako pođemo od Blumfildovog (1933) stanovišta da pismo odražava govor, i Manrikeove (1988:161) definicije pisma kao "sistema sposobnog da u potpunosti grafički zabeleži govor, a potom čitanjem ponovo reprodukuje i to uvek na isti način", onda astečko pismo ne možemo smatrati pismom u punom smislu te reči, prvenstveno zato što ne postoji precizno utvrđen način kodifikacije, niti čitanja glifova ${ }^{10}$. Sa druge strane, njime se beleže samo određeni tipovi podataka (imena ljudi, mesta, bogova, važni datumi, administrativ-

$6 \quad$ Wittaker (2010:936) koristi termin morfogram umesto pomenutog logogram, koji obuhvata ne samo leksičke, već i (malobrojne) gramatičke morfeme.

Indirektni logogram je drugi naziv za ono što se tradicionalno imenuje kao ideogram.

Zatvorene slogove Lacadena smatra logogramima.

Fra Bernardino de Saagun uveravao je da "ovi ljudi nisu imali slova, niti su znali čitati i pisati, već su se sporazumevali pomoću slika i crteža" (Sahagún, 1981: 165) Mada se često čitaju odozdo na gore i sa leva na desno. 
ni podaci). Ne beleži se gotovo nikakva gramatička informacija, izuzev pojedinih lokativa (-c(o), -pan, -tlan), posesiva -hua (cf. Lacadena, 2008c). Iz tih razloga, Leonardo Manrike (1988) ga naziva polupismom hijeroglifskog tipa, a u sličnom duhu su ga okarakterisali Prem (1992) kao "ograničeni sistem", Barthel (1968) "delimični sistem".

Nasuprot ovako rigidnom određenju pisma, stoje i ona manje restriktivna koja pod pojmom pisma podrazumevaju "a system of human communication by means of conventional visible marks" (Gelb, 1963:12, citat prema Mikulska Dąbrowska, 2008:23). Ovako shvaćen pojam pisma svako obuhvata i astečki sistem beleženja.

\section{Analiza antroponima ${ }^{11}$}

Antroponimski glifovi su lako uočljivi u svakom kodeksu, zato što se nalaze pored osobe na koju se odnose (bilo iza nje, ili iznad glave) i pri tom su povezani tankom linijom, kao što se vidi u detalju sa prvog lista kodeksa Šolotl.

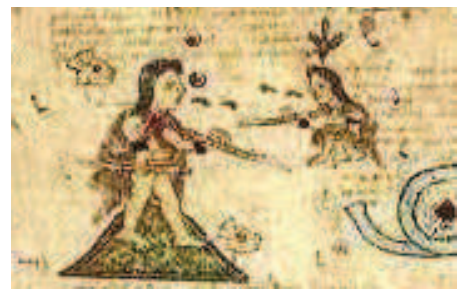

2) Šolotl i Nopalcin. Kodeks Šolotl, list 1, detalj

Imena u kodeksu Šolotl sastoje se najčešće od imenice (Cohuatzin), složenice od dve imenice (Cozcacuauh), prideva i imenice (Iztacmitl), imenice i glagola (Itzcuintecua) ili od broja (Nauhyot/).

U nastavku rada glifovi će biti analizirani prema tipu (direktni ili indirektni logogram), i prema strukturi glifa (prosti, složeni i sliveni).

\subsection{Direktni logogrami}

Direktni logogrami su oni kod kojih se transkribuje reč ili osnovu reči koja odgovara nacrtanom objektu ili radnji, kao na primer glava orla koja se čita "cuauhtli" ili "cuauh".

11 U analizi antroponima koristiću Lakadeninu notaciju (Lacadena, 2008a), preuzetu iz majanske epigrafije, a koja podrazumeva sledeće: transkripcija glifa se beleleži masnim slovima, pri čemu su elementi glifa razdvojeni crticom; logogrami se pišu velikim slovima, a fonogrami malim. Transliteracija je data u kurzivu. U uglastim zagradama je neiskazani deo antroponima, a u izlomljenim glosa. 


\subsubsection{Prosti direktni logogrami}

Prosti direktni logogrami sastoje se samo od jednog elementa. $\mathrm{Na}$ prvom listu kodeksa nalazi se svega 5 takvih glifova: ime Šolotla, ćićimečkog monarha, koje je predstavljeno profilom psa ${ }^{12}$; njegovog sina i naslednika Nopalcina (NOPAL Nopal[tzin], od imenice nopalli kojom se označava vrsta kaktusa), kao i ime vladara Tekošemaka, Kouacina (CŌHUĀ Cōhuā[tzin], od cōhuātl "zmija").

Strela, MITL, ime je gospodara Tlacan-Tlalanostoka, koji se alternativno naziva i TLACOCHTLI Tlacochtli (tlacochtli, "koplje), TLACÔ Tlacò[tzin] (tlacòtli, "motka"), dok je TECPA Tecpa[n] (od tecpatl "kameni nož" ${ }^{13}$ ) jedan od šest ćićimečkih vođa koji je stigao sa Šolotlom.

\subsubsection{Složeni direktni logogrami}

Složeni direktni logogrami sastoje se od dva ili više elemenata koji su obično postavljeni jedan do drugog (jukstapozicija), bilo u vertikalnoj osi, horizontalnoj ili kombinaciji ove dve (Thouvenot, 2012). Funkcionišu po principu rebusa, koji Wittaker (2010a:937) definiše kao "the secondary use of a morphogram for its phonetic value alone".

Različite interpretacije ovog složenog glifa vertikalne kompozicije, koji se se sastoji od glave ptice i simbola za oko ${ }^{14}$ (ixtelolòtli), potiču od tumačenja o kojoj vrsti ptice se radi, da li o orlu (cuāuhtli) ili sokolu (tohtli), pa je u skladu sa tim jedna od vrednosti ovog glifa CUĀUHTLI-īx Cuauhtlix, kako stoji u hronici Alve Ištlilšoćitla:

Los señores que quedaron en éstas fueron los que siguen: en Culhuacan Cuauhtlix con su mujer IImixuch, y un hijo Ilamado Acxocuauh...

"Gospodari koji su ostali na ovim prostorima su sledeći: u Kuluakanu, Kuautliš (Cuauhtlix) i žena mu IImišuć (Ilmixuch), i sin zvani Akšokvau (Acxocuauh)."

Sa druge strane, alternativni oblik koji je prihvatio Dibble (1980) u svojoj analizi je TOHTLI-ix [Ca]tohtlix,"Catohtlix", prema glosi <catohtlix> koja je zabeležena u kodeksu. Pri tom, inicijalni slog ca- je neiskazan i

12 U pitanju je meksička rasa psa bez dlake, koji se naziva xoloitzcuintli. Ono po čemu se prepoznaje ovaj glif jesu uši, koje nisu zašiljene kao kod "običnog" psa (itzcuintli), već deluje kao da su zasečene.

13 Tecpatl se koristio u ritualne svrhe u obredima žtrvovanja.

14 Thouvenot (2012) tvrdi da može biti i indirektni logogram sa vrednošću tlachia "videti, gledati", kao što je zabeleženo u La Matrícula de Huexotzinco. 
rekonstruisan na osnovu same glose, a njegovo poreklo i dalje je nepoznanica. Ipak, na osnovu same grafičke reprezentacije glave ptice, koja nesumnjivo predstavlja orla, ne može se prihvatiti "Catohtlix".

Ono što je neobično u ovim transkripcijama glifa (7) jeste inkorporacija čitavih imenica cuāuhtli i tohtli, a ne samo njihovih osnova cuāuh- / toh- kako bi se očekivalo (uobičajena forma bila bi cuāuhīxtli / catohīxtli).

Element orla prisutan je i u imenu Kuautlišovog sina Akšokvau. U pitanju je glif mešovite kompozicije, sastavljenog od tri elementa: glave orla (cuauhtli), vode (ātl) i noge/ stopala. Budući da "znaci u složenici ne moraju da transkribuju linearni niz fonema, ali moraju barem prvi V ili CV slog reči"15 (Lacadena, 2008a:8), onda u ovom slučaju sekvenca -cxo- može da bude ili od icxitl, kako sugeriše Dibble (1980), gde je osnova $c x i^{-16}$, ili xocpalli "taban" koji ima fonetsku vrednost xo- (Thouvenot 2012, Aubin 2009 [1884], Lacadena 2008b). U svakom slučaju, to ne utiče na čitanje glifa, već samo na njegovu analizu: ā-cxi-CUĀUH Acxocuauh ili à-xo-CUĀUH "A[c]xocuauh".

Element vode (āt/), koji zauzima donju polovinu glifa, i cvet (xōchit/) koji je drugačiji od svih ostalih u kodeksu u gornjoj, čine složeni glif problematične interpretacije. Primenom rebusa dolazimo do vrednosti a-XOCHITL Axochitl, što se nazire u anotaciji u kodeksu. Dibble, pak, udvostručava vrednost elementa ātl (mada nije jasno na osnovu čega), koji se pojavljuje kao fonogram a na početku izraza, i kao logogram ĀTL na kraju: ā-XōCHI-ĀTL Axochiatl. Sa druge strane, Thouvenot je, bazirajući se na kodeksu Florentino, identifikovao ovaj cvet kao matlalli, pa je otuda njegova interpretacija MATLAL-a Matlala[tzin].

Ime Šolotlove žene tō-MIYĀUH "Tomiyauh" sastoji se od tōtōtl "ptica" + miyāhuatl "klas kukuruza". U samom kodeksu, na jednom od mesta gde se govori o Šolotlu, stoji glosa <in icihuauh tomiyauh> ("njegova žena je Tomiyauh"), a isti oblik antroponima beleži i Alva Išlišoćitl u svojoj hronici, gde se kaže: Este gran chichimecatl traía por mujer a la reina Tomyauh "ovaj veliki Ćićimek imao je za ženu kraljicu Tomiyauh".

Mitl "strela" i iztāc "belo" elementi su složenog glifa horizontalne jukstapozicije kojim se označava ime jednog od ćićimečkih vođa, MITL-

15 Wittaker (2009: 62-3), nasuprot, smatra da to nije isključivo i daje primer u kojem se transkribuje medijalni slog reči.

$16 \quad c f$. oblik no-cxi "moja noga", gde se inicijalno i- iz icxit/ gubi u derivaciji pred prefiksom no-. 
IZTĀC Mitliztāc ili IZTĀC-MITL Iztācmitl, kako ga interpretira Dibble (1980). Lingvistički posmatrano, obe interpretacije su prihvatljive, jer pridevi mogu da stoje kako u prenominalnom, tako i u postnominalnom položaju (Launey, 1992), bez ikakve razlike u značenju. Međutim, kod antroponima IZTĀC-CUĀUHTLI Iztāccuāuhtli (iztāc "belo" i cuāuhtli "orao") nije zabeležen alternativni oblik Cuāuhtliztāc/Cuāuhiztāc, sa pridevom u postnominalnom položaju.

Ogrlica od tirkiza na kožnom lancu (cōzcatl) i glava orla (cuāuhtli) daju složeni glif od dva direktna logograma: CōZCA-CUĀUH Cōzcacuāuh <glosa: cozcaquautli>.

"Pero" ihuitl i "cvet" xōchit/ kombinuju se vertikalnom jukstapozicijom u složeni glif ÌHUI-XŌCH Ihuixōch[itzin], što beleži i Alva Ixtlixochitl u obliku "ilmixuch". Nasuprot tome, Dibble interpretira ovaj glif kao XIHUIXŌCH (xihuitl "biljka") na osnovu glose u kodeksu <xihuixoch>, ali to ne odgovara grafičkoj reprezentaciji. Sa druge strane, imenica xihuitl je izuzetno polisemična i, osim biljke, znači i "tirkiz", "drago kamenje", "godina", "kometa", "vreme". U samom kodeksu fonetska vrednost "xihui" je prisutna u glifovima koji označavaju godinu ili tirkiz, drago kamenje ${ }^{17}$ (ali ne i u značenju "biljka").

Složeni glif vertikalne kompozicije, kojim se označava ime Mitline supruge Koašoćitl, sastoji se od dva logograma CōHUA-XŌCHITL Cōhuaxōchitl <glosa: cohuaxochitl> (od cōhuatl "zmija" i xōchitl "cvet"), dok Thouvenot rekonstruiše sufiks -tzin: CōHUA-XŌCH Cōhuaxōch[itzin].

Fonogram itz od itztli "opsidijan", predstavljen crnom bojom u gornjoj polovini glifa i logogram CAX, odnosno CAXITL ("posuda"), elementi su složenog glifa vertikalne kompozicije itz-CAX Itzcax / itz-CAXITL Itzcaxitl. Na vrednost Itzcaxitl upućuje glosa u kodeksu: in ypiltzin itoca itzcaxitl “njegov/njen sin se zove Itzcaxitl".

\subsubsection{Sliveni direktni logogrami}

Element jaguara, koji uvek ima vrednost "ocelo", predstavlja se ili glavom jaguara ili tačkicama. Kako zapaža Thouvenot (2012), kada je "oceIo" na početku izraza, onda se glif elementa ōcēlōtl nalazi ispod drugog elementa i čita se odozdo na gore, dok u slučaju inkorporacije, čita se prvo

17 Ima 11 glifova sa elementom xihuit/ u značenju "godina" (10 su datumi i 1 toponim) i 2 antroponima u kojima se xihuit/ odnosi na tirkiz. 
unutrašnjost glifa, a potom njegova spoljašnjost, kao što se može videti u antroponimu Oselošoćitl (supruga vladara Šiutemala iz Kuluakana): ŌCĒLŌ-XŌCHITL Ōcēlōxōchitl <glosa: oceloxochitl> (od ōcēlōtl "jaguar" i xōchitl "cvet").

\subsection{Indirektni logogrami (ideogrami)}

Kod indirektnih logograma crtež predmeta ili radnje transkribuje reč koja odgovara ideji koja se njom povezuje. Tako, na primer, ptica raširenih krila čita se kao patlani "leteti”. Nekada je teško razlučiti da li je analizirani glif direktni ili indirektni logogram, što se vidi u narednim primerima.

\subsubsection{Prosti indirektni logogram}

Glif kojim se beleži ime sina vladara Kuluakana, Šiutemoka i Oselošoćitl, sastoji se od simbola za broj četiri ${ }^{18}$ (četiri vertikalne crte, mada se u te svrhe mogu koristiti i krugovi), koji ima fonetsku vrednost nahui. Pošto je na osnovu zapisa iz kodeksa rekonstruisan sufiks $-\left.y \bar{o} t\right|^{19}$, koji se koristi za građenje apstraktnih imenica, onda je za fonetsku vrednost broja "četiri" uzeta osnova nauh- koja je uvek prisutna u derivaciji: NAHUI Nauh[yotl] "Nauhyotl" <glosa:nauhyotl>. Osim u glose kodeksu, ovaj oblik je potvrđen i kod Alve Išlišoćitla:

Murió Xiuhtemoc, el señor de Culhuacan [...] heredándole en el señorío Nauhyotl, su hijo. (Alva Ixtlilxochitl, 1891 (t.I): 90)

"Umre Šiutemok, gospodar Kuluakana [...] nasledi ga Naujotl, sin njegov".

A(c)xopal / Ameyal - vladar Kećolana, sin Koašoćitl i Mitle, i brat Pišauin. Ovaj glif ima dve moguće interpretacije. Ako uzmemo da se radi o složenom direktnom glifu, primenom principa rebusa dobijamo ā-XŌPAL $\bar{A} x o ̄ p a l^{20}$, od ātl "voda" i prideva xōpalectic, xōpalehuac, kojim se označava

$18 \quad$ Klasifikacija ovog glifa je problematična. Budući da vertikalne crte koje ga čine nisu upotrebljene u svom primarnom značenju (tlaxotla, tlecotl, tetlecoliztli, tlahuahuantli, sve sa značenjem "crta") već imaju numeričku vrednost, svrstala sam ga u indirektne logograme. Što se strukture glifa tiče, ne može da bude ni složeni, ni sliveni, zbog odsustva jukstapozicije, odnosno inkorporacije. Sa druge strane, sastoji se od samo jednog znaka (iako više puta ponovljenog), zbog čega sam ga ipak uvrstila u proste glifove.

19 Aubin (2009 [1884]: 49) navodi da je u kodeksu Vergara sufiks -yotl iskazan pomoću fonograma izvedenog od elementa yoyotli, coyolli "klepetuše". 
intenzivna zelena boja. Sa druge strane, uzimajući u obzir činjenicu da se glif sastoji od mlaza vode koji izlazi iz kruga, to bi se moglo shvatiti kao izvor, $(\bar{a}) m e \bar{y} a l l i$, te bi alternativno tumačenje glifa kao indirektnog logograma bilo ā- $(\overline{\mathbf{A}}) \mathbf{M E} Y \mathbf{A L}$, pri čemu je inicijalni fonogram a- ovde dopunski znak (cf. Nutall 2008 [1888]) koji služi da precizira fonetsku vrednost znaka (u konkretnom slučaju, da se čita kao "āmēyal", a ne "mēyal"). Međutim, problem je u tome što ne postoji potvrda u istorijskim dokumentima za takvu interpretaciju. Takođe, u samom kodeksu nalazimo glosu, verovatno zabeleženu od strane Alve Ištlilšoćitla, u kojoj se ime vladara Kećolana pojavljuje u varijanti <accopatl>:

Oncan tlacatque inipilhuan in Pizahua ${ }^{21}$ ihuan // in Accopatl in Toltecatl

"Tamo su se rodili njihovi sinovi Pisaua i Akopatl Toltek" (prevod autorov).

Ipak, budući da se oblik Accopatl sastoji od copalli "tamjan", ovakvu interpretaciju smatram grafički neosnovanom.

Glif vertikalne juktsapozije koji se sastoji od dva elementa: trske $\bar{a} c a t /$ u gornjoj polovini, i četiri crvena kruga u donjoj. Ako ga analiziramo kao indirektni logogram, onda ta četiri kruga sa manjim krugovima u sredini, mogu da predstavljaju sunce, a zbog crvene boje i toplotu, odnosno dan tōnalli (cf. Hill Boone, 2010:47-8). U tom slučaju, vrednost ovog glifa bi bila ĀCA-TŌNAL. Sa druge strane, Charles Dibble (1980) smatra da crveni krugovi nisu ništa drugo do paradajz, tomatl, odakle dobijamo ime ĀCA-TOMATL (direktni logogram). lako je takva vrednost prisutna i kod Thouvenota (2012), njegova analiza je drugačija - mišljenja je da se radi o složenom glifu koji se sastoji od logograma ĀCA i ĀTL, na koju ukazuju mali krugovi u onim većim, i sloga -tōm-, kao varijante od tōnalli (ĀCAtōm-ĀTL). Teško je prihvatiti jednu ili drugu interpretaciju samo na osnovu lingvističke analize, a i sami istorijski izvori u ovom slučaju su podeljeni. Kod Alve Ištlilšoćitla se javlja Acatomatl, dok u samom kodeksu Šolotl stoji glosa <acatonal>.

Ovoj grupi glifova pripada i ZACA-COCHI Zaca[titech]cochi "Zacatitechcochi" (od zacatl "slama", titech "u, na", cochi "spavati"). Glagol cochi, predstavljen profilom osobe sa zatvorenim očima, ima vrednost "coch". kada se nalazi u inicijalnom položaju izraza.

$21 \quad$ Pizahua ovde stoji umesto Pixahua. 
Brojni glifovi koji sadrže cuā "jesti / tēcuā "ugristi" nesumnjivo su indirektni logogrami, jer na ovo značenje upućuju usne, tentli, bilo otvorene ili zatvorene.

Takvi su antroponimi ITZCUĪN-TĒCUĀ Itzcuīntēcuā, (od itzcuīntli "pas"), TEPOTZÒ TĒCUĀ Tepotzòtēcuā (od tepotzòtli "grbav"). Međutim, Thouvenot (2012) deli logogram TËCUĀ, po mom mišljenju neopravdano, na te-CUĀ, pri čemu su i fonogram te i indirektni logogram CUĀ fonetske vrednosti jednog te istog elementa (tent/i). Dibble, sa druge strane, u potpunosti ignoriše te.

Element (te)cua nalazimo u glifovima tzon-CUĀ [Xiyo]tzoncua i TËCUĀ [Xiyo ${ }^{22}$ ]tecua u kojima jedan od njihovih elemenata još uvek nije identifikovan ${ }^{23}$ ali je rekonstruisan kao xiyo na osnovu istorijskih spisa. Što se tiče Xiyotzoncua, fonogram tzon- mogao bi se dovesti u vezu sa imenicom tzontli "kosa", kao što to čini Dibble, ali Thouvenot (2012) pokazuje da ne postoji grafička veza između ovog glifa i tzontli i kao rešenje navodi centzontli ("broj 400", "mnogo", "vrsta biljke"), čija je fonetska vrednost u kompoziciji takođe uvek tzon.

\subsubsection{Sliveni indirektni logogram}

Zbog crvene boje inkorporirane u disk (cōlōtli), ovaj glif se smatra slivenim, a pošto ovde crvena boja nije potrebljena u svom primarnom značenju (chiltic, chichiltic), već upućuje na $\mathrm{krv}^{24}$ (eztli) ${ }^{25}$ pripada grupi indirektnih logograma ${ }^{26}$, čija je vrednost ez-CōLōTLI, Ezcōlōtli.

\section{Zaključak}

Uprkos Aubinovom uverenju da je astečko pismo silabičkog tipa, ova analiza pokazala je da se to samo delimično tačno i da je u pitanju logo-silabičko pismo sa elementima fonetizma, što se slaže sa .Lakadeninim mišljenjem (2008). Nasuprot Zenderu (2008) koji izričito negira post-

22 Dibble takođe navodi varijantu xico, ali ne daje objašnjenje čime je to motivisano.

23 U rečnicima postoji imenica xiyotl, ali nijedno od njenih značenja ne može da se dovede u vezu sa ovim glifovima ("ekcem", "vrsta razboja", "primer").

cf. Aubin, 2009 [1884]:39. Osim toga,

cf. Pridev eztic "obojen, crven", izveden od imenice eztli (Karttunen, 1992).

Ceo glif je indirektni logogram, a sekvenca ez- fonogram, tj. silabogram. 
ojanje ideograma, videli smo da je jednu trećinu analiziranih glifova čine upravo indirektni logogrami ili ideogrami. Takođe se ukazalo na probleme sa kojima se susrećemo prilikom intrepretacije glifova, kao i na važnost istorijskih dokumenata.

\section{Bibliografija}

Alva Ixtlilxochitl, Fernando de. Obras Históricas, 2 toma. Universidad Nacional Autónoma de México, Instituto de Investigaciones Históricas, 1985.

Alva Ixtlilxochitl, Fernando de. Obras Históricas de Don Fernando de Alva Ixtlilxochitl, Publicadas y Anotadas por Alfredo Chavero. Secretaría de Fomento, 1891.

Aubin, Joseph Marius Alexis. Memorias Sobre la Pintura Didáctica y la Escritura Figurativa de los Antiguos Mexicanos. Universidad Nacional Autónoma de México, 2009 [1884]

Barthel, Thomas. "Writing systems", u Thomas A. Sebeok (izd.), Current Trends in Linguistics, IV: Ibero-American and Caribbean Linguistics. Mouton, 1968, 275-301.

Bloomfield, Leonard. Language. Holt, Rineheart \& Winston, 1933.

Clavijero, Francisco Xavier. "Vocabulario", u Reglas de la Lengua Mexicana con un Vocabulario. Elektronsko izdanje: Sybille de Pury, Danièle Babout, Marc Thouvenot, u GDN: Gran Diccionario Náhuatl, 2007 (1780). www.sup-infor.com

Cortés y Zedeño, Jerónimo Thomas de Aquino. "Diccionario de Romance a Mexicano", u Arte, Vocabulario y Confessionario en el Idioma Mexicano Como Se Usa en el Obispado de Guadalajara. Elektronsko izdanje: Sybille de Pury, Danièle Babout, Marc Thouvenot, u GDN: Gran Diccionario Náhuatl. 2006 (1765). www.sup-infor.com

Dibble, Charles (izd.). Códice Xolotl, 2 toma. Universidad Nacional Autónoma de México, 1980.

Hill Boone, Elizabeth. Relatos en Rojo y Negro. Historias Pictóricas de Aztecas y Mixtecos. Fondo de Cultura Económica, 2010.

Karttunen, Frances. An Analytical Dictionary of Nahuatl. Oklahoma Press, 1992.

Lacadena, Alfonso. "Regional Scribal Traditions: Methodological Implications for the Decipherment of Nahuatl Writing", The PARI Journal, vol. VIII, no. 4, 2008a, 1-22.

Lacadena, Alfonso. "A Nahuatl Syllabary". The PARI Journal, vol. VIII, no. 4, 2008b, 23.

Lacadena, Alfonso. "The $w a_{1}$ and $w a_{2}$ Phonetic Signs and the Logogram for WA in Nahuatl Writing". The PARI Journal, vol. VIII, no. 4, (2008c): 38-45.

Launey, Michel. Introducción a la Lengua y a la Literatura Náhuatl. Universidad Nacional Autónoma de México, Instituto de Investigaciones Antropológicas, 1992.

León- Portilla, Miguel. Códices. Los Antiguos Libros del Nuevo Mundo. Aguilar, 2003.

León-Portilla, Miguel. El Destino de la Palabra: de la Oralidad y los Glifos Mesoamericanos a la Escritura Jeroglífica. El Colegio Nacional/ Fondo de Cultura Económica, 1996. 
León-Portilla, Miguel. "El Proceso de Aculturación de los Chichimecas de Xólotl”, Estudios de cultura náhuatl 7, 1967, 59-86.

León-Portilla, Miguel. “La Riqueza Semántica de los Códices Mesoamericanos", Estudios de cultura náhuatl, vol. 43, 2012, 139-160.

Manrique Castañeda, Leonardo. "Ubicación de los Documentos Pictográficos de Tradición Náhuatl en una Tipología de Sistemas de Registro y Escritura". Memorias del Primer Coloquio de Documentos Pictográficos de Tradición Náhuatl, Serie de Cultura Náhuatl. Instituto de Investigaciones Históricas/Universidad Nacional Autónoma de México, 1988, 159-170.

Mikulska Dabrowska, Katarzyna. El Lenguaje Enmascarado. Un Acercamiento a las Representaciones Gráficas de Deidades Nahuas. UNAM, IIA/ Sociedad Polaca de Estudios Latinoamericanos/ Universidad de Varsovia, Facultad de Neofilología, Instituto de Estudios Ibéricos e Iberoamericanos, 2008.

Miller, Mary \& Karl Taube. An Illustrated Dictionary of the Gods and Symbols of Ancient Mexico and the Maya. Thames \& Hudson, 1993.

Molina, fray Alonso de. Vocabulario en la Lengua Castellana/Mexicana, Mexicana/Castellana. Editorial Porrúa, 2004 [1555].

Nicholson, Henry B. "Phoneticism in the Late Pre-hispanic Writing System", u E. P. Benson (ur.) Mesoamerican Writing Systems. A Conference at Dumbarton Oaks, October $30^{\text {th }}$ and $31^{\text {st }}, 1971$, Dumbarton Oaks, 1974, 1-26.

Nicholson, Henry B. "The Native Tradition Pictorials in the Aubin-Goupil Collection of Mesoamerican Ethnohistorical Documents in the Bibliotheque Nationale de France: Major Reproductions ans Studies", Journal de la Societé des Américanistes, t. 84, no. 2, 1998, 35-50.

Nuttall, Zelia. "On the Complementary Signs of the Mexican Graphic System", The PARI Journal, vol. VIII, no. 4, 2008, 45-48.

Prem, Hanns Jürgen. 1992. "Aztec Writing", u Victoria Reifler Bricker (izd.), Handbook of Middle American Indians, Supplement, Vol. V: Epigraphy. University of Texas Press, 53-69.

Sahagún, fray Bernardino. Historia General de las Cosas de la Nueva España, izdanje Ángel María Garibay. Porrúa, 1981.

Siméon, Rémi. Diccionario de la Lengua Náhuatl o Mexicana. Prevod sa francuskog Josefina Oliva de Coll. Siglo XXI, 2007.

Thouvenot, Marc. Tlachia [online]. Universidad Nacional Autónoma de México [Ciudad Universitaria, México D.F.]: 2012 <http://tlachia.iib.unam.mx>

Thouvenot, Marc. "Imágenes y Escritura de los Nahuas del Inicio del XVI", Estudios de cultura náhuatl, vol. 41, 2010, 167-191.

Thouvenot, Marc. GDN, Grand Dictionnaire Nahuatl, programme informatique, 2005. www. sup-infor.com

Thouvenot, Marc. Tlachia, Logiciel pour des Dictionnaires Pictographiques, programme informatique, 2003. www.sup-infor.com

Whittaker, Gordon. "The Principles of Nahuatl Writing", Göttinger Beiträge zur Sprachwissenschaft 16, 2009, 47-81. 
Whittaker, Gordon. "Nahuatl Hieroglyphic Writing and the Beinecke Map", u Mary Miller i Barbara Mundy (izd.), The Beinecke Map and the Indigenous World in SixteenthCentury Mexico. Yale University Press/Beinecke Library, 2010b, 137-157.

Whittaker, Gordon. 2010a. "Writing Systems", u Patrick Holm Hogan (izd.), The Cambridge Enciclopedia of the Language Sciences. Cambridge UP, 2010a, 935-939.

Wolgemuth, Walters et al. Diccionario Náhuatl de los Municipios de Mecayapan y Tatahuicapan de Juárez, Veracruz. Elektronsko izdanje: Sybille de Pury, Marc Thouvenot, u GDN: Gran Diccionario Náhuatl. 2006 (2002) www. sup-infor.com.

Zender, Marc. "One Hundred and Fifty Years of Nahuatl Decipherment", The PARI Journal, vol. VIII, no. 4, 2008, 24-37. 